\title{
Targeting efficiency of $\alpha-1,3$-galactosyl transferase gene in pig fetal fibroblast cells
}

\author{
Dong-II Jin ${ }^{1,3}$, Seung-Hyeon Lee \\ Jin-Hee Choi ${ }^{1}$, Jae-Seon Lee ${ }^{1}$ \\ Jong-Eun Lee', Kwang-Wook Park ${ }^{4}$ and \\ Jeong-Sun $S e 0^{1,2,5}$ \\ 'Ilchun Molecular Medicine Institute \\ Medical Research Center \\ Seoul National University, Korea \\ ${ }^{2}$ Department of Biochemistry and Molecular Biology \\ Seoul National University College of Medicine, Korea \\ ${ }^{3}$ Division of Animal Science and Resources \\ Research Center for Transgenic Cloned Pigs \\ Chungnam Nafonal University, Korea \\ "MGenbio, Inc., Korea \\ ${ }^{5}$ Corresponding author: Tel, 82-2-740-8246; \\ Fax, 82-2-741-5423; E-mal, jeongsun@snu.ac.kr
}

Accepted 12 December 2003

Abbreviation: 13-GT, of 1,3-galactbsyl transferase; HSV-tk, herpes simplex virus-thymidine kinase; $\mathrm{NeO}^{\prime}$, neomycin phosphotransferase

\begin{abstract}
Animal cloning technology with somatic cells provides an alternative tool to conventional methods for producing transgenic animals. Gene targeting in animals is made feasible using somatic cells with homologous recombination procedure that is a major technique in embryonic stem cells for knocking-out genes. Homologous recombination events in somatic cells are relatively inefficient as com. pared to those in ES cells, suggesting the need for establishment of efficient gene targeting syste $m$ in somatic cells. To investigate the efficiency of positive and negative selection for gene targeting in pig fetal fibroblast cells, pig $\alpha-1,3-g$ alactosyl transferase (13-GT) gene was used for gene targeting. The neomycin phosphotransferase (Neo') and herpes simplex virus-thymidine kinase (HSV-tk) genes were used as positive and negative selec. tion markers in this experiment. Following trans. fection with targeting DNA construct, the pig fetal fibroblast cells were selected against resistance of G418 and gancyclovir. In DMEM medium containing 5 to $10 \%$ serum, Pig fetal fibroblast cells failed
\end{abstract}

to proliferate during drug selection. Increasing serum concentration to $15 \%$ of medium yielded less senescent colonies of pig fetal fibroblast cells following drug selection that allowed enough cell colonies to screen genomic DNA. The frequency of gene targeting in pig fetal fibroblast cells with double drug selection was more than 10 -fold efficient compared to that with G418 single selection. Double selection method with Neo' and HSV-tk genes could be useful for gene targeting in somatic cells for production of cloned animals carrying targeted endogenous genes.

Keywords: animal cloning; galactosyltransferases; gene targeting; swine

\section{Introduction}

Recent development of animal cloning technology with somatic cells provides an alternative tool to conventional methods for modifying genes in animal (Wilmut et al., 1997). DNA-inserted somatic cells can be selected in dishes and then nuclear transfer can be done with those cells (Schnieke et al., 1997; Cibelli et al., 1998; Zakhartchenko et al., 2001). Gene targeting in animals is feasible using somatic cells with homologous recombination procedure that has been a major technique in embryonic stem cells for knockingout genes. Nuclear transfer of somatic cells in pigs is the most promising procedure to achieve knockout of $\alpha-1,3$-galactosyl transferase (13-GT) gene for pigto-human xenotransplatation (Betthanser et al., 2000; Onishi, et al., 2000; Polejaeva, et al., 2000; Harrison et al., 2002). Production of viable pig and sheep with targeted insertion at several gene loci following nuclear transfer with gene-targeted cells has been reported (McCreath et al., 2000; Denning et al., 2001; Dai et al., 2002; Lai et al., 2002; Phelps et al., 2003; Ramsoondar et al., 2003).

Most somatic cells for nuclear transfer in animals are fetus-derived primary cells that are different from stem cells in terms of culture condition, strength of passing or drug selection. For gene targeting, extensive drug selection is required that makes primary cells to stop proliferation or to grow slow. One of the key steps in gene targeting is the selection system to enrich for somatic cells in which correct homologous recombination has occurred. The single selection with neomycin phosphotransferase $\left(\mathrm{Neo}^{\prime}\right)$ gene 
has been a popular method in gene targeting of somatic cells probably due to weakness of proliferation ability following drug selection of primary somatic cells (McCreath et al., 2000; Denning et al., 2001; Dai et al., 2002; Lai et al., 2002). The double (positive/negative) selection procedure developed by Mansour et al. (1988) and Capecchi (1989) has been effectively used for gene targeting in mouse ES cells. The herpes simplex virus (HSV) thymidine kinase (tk) gene allows for selection against random insertion events with the selective drug, gancyclovir that eliminates HSV-tk geneintegrated cells during selection. In ES cell system, the single positive selection results in a 1,000-fold enrichment for targeted cell line and the double selection procedure achieves an additional $10-$ to 1,000 -fold enrichment (Riele, et al., 1992). The double selection method could have been much more effective in somatic cells over single selection procedure when strength of cell proliferation is sustained during drug selections. To date, there have been no other reports of successful gene targeting in somatic cells with the double positive-negative selection procedures. G418 and gancyclovir that have been used during positivenegative selection could be detrimental for proliferation of primary sometic cells.

Therefore, to determine whether positive-negative gene targeting could be achieved in pig fetal fibroblasts, pig genomic 13-GT gene was cloned from pig genomic library and $\mathrm{Neo}^{\prime}$ plus HSV-tk genes were used for the construction of targeting vector in this experiment. Following transfection with targeting vector DNA, the pig fetal fibroblast cells were selected against resistance of $\mathrm{G} 418$ and gancyclovir. Our results indicate that the gene targeting in pig fetal fibroblasts can be achieved by using double selection procedure with high targeting efficiency.

\section{Materials and Methods}

\section{Isolation of 13-GT DNA}

Pig genomic DNA library (BD Biosciences Clontech) was screened with 560 -bp fragment of exon 9 amplified by PCR of pig cDNA library. Screening was performed using nylon membranes and a genomic library of $3 \times 10^{5}$ plaques per each membrane was used with ${ }^{32} \mathrm{P}$-radiolabelled probe. Positive plaques were confirmed by spot testing and clonally purified by titration of phage plug dilutions onto $E$. coli KW251 lawns. Positive phage DNA was isolated from $50 \mathrm{ml}$ cultures of lysed $E$. coli KW251 using RNase A/D Nase I digestion of bacterial nucleotides and precipitation of phage particles with polyethylene glycol. A 11-kb 13-GT hybridizing fragment from a recombination phage was subcloned into the pBluescript(+) and transformed into E. coli XL1-Blue. A 13-GT frag- ment was partially sequenced by using the Sequenase sequencing kit (United States Biochemical, Cleveland, $\mathrm{OH}$ ). Primers used were the pBluescript(+) forward primer and revere primer. The distribution of restriction enzyme sites in 13-GT fragment was identified with several restriction enzymes.

\section{Targeting vector construction}

Knock-out plasmid, pPNT that has Neo' and HSV-tk genes was used for construction of 13-GT targeting vector. The targeting vector consisted of a $8 \mathrm{~kb}$ NotlXhol fragment from part of intron 7 , exon 8 and part of intron 8 as the long arm, a 1.9-kb neomycin-resistant gene, a $0.75-\mathrm{kb} X$ bal-BamHI fragment derived from exon 9 as the short arm, and a 3.4-kb fragment containing the herpes simplex virus thymidine kinase gene. Noth-linearized targeting vector was used for electroporation into pig embryonic fibroblast cells.

\section{Preparation and transfection of porcine fetal fibroblasts}

Pig fetal fibroblast cells were isolated from 8 fetuses of the pregnancy at day 25 of gestation. After removing the head and viscera, fetuses were washed twice with PBS. The red tissues and brain tissues of each fetus were removed and cut as small as possible. And then tissues were treated with trypsin $(0.25 \%)$ and shaken for $30 \mathrm{~min}$ in $37^{\circ} \mathrm{C}$ incubator. The only supernatant was poured into a $50 \mathrm{ml}$ centrifuge tube mixed with an equal volume of DMEM with $10 \%$ FBS and put in ice. This procedure was repeated once more and cells were pelleted following centrifugation at $500 \mathrm{~g}$ for $10 \mathrm{~min}$. The supernatant was aspirated off, and cells were resuspended with DMEM. The cells were planted into culture dishes and cultured at $37^{\circ} \mathrm{C}, 5 \% \mathrm{CO}_{2}$ incubator. The only cells dividing into monolayer were considered to be $\mathrm{P}_{0}$ and cells with next passing were numbered to be $P_{1}$. The cells were cryopreserved in liquid nitrogen using freezing medium (11\% DMSO, 50\% FBS, $39 \%$ DMEM). For transfection experiments, $\mathrm{P}_{2}$ or $\mathrm{P}_{3}$-stage cells were used in this experiment.

For transfection of DNA, $10 \mu \mathrm{g}$ of linearized vector DNA was introduced into 2 million cells by electroporation. The cell-DNA mixture were loaded into an electorporation chamber, and exposured to a $1 \mathrm{~s}$ electrical pulse from $250 \mathrm{~F}$ capacitator charged to 300 V. Cells were immediately plated into $100-\mathrm{mm}$ culture dishes. Forty-eight hours after transfection, the transfected cells were selected with $200 \mu \mathrm{g} / \mathrm{ml}$ of $\mathrm{G} 418$ (Gibco-BRL) and $3 \mu \mathrm{M}$ of gancyclovir for 10-14 d.

\section{Identification of targeted cells}

Cells were resuspended in lysis buffer $(40 \mathrm{mM}$ Tris, 
pH $8.9,0.9 \%$ Triton X-100, $0.9 \%$ Nonidet P-40, 0.4 $\mathrm{mg} / \mathrm{ml}$ proteinase $\mathrm{K}$ ), incubated at $55^{\circ} \mathrm{C}$ for $5 \mathrm{~h}$ and heated to $95^{\circ} \mathrm{C}$ for $10 \mathrm{~min}$ to inactivate the proteinase K. For PCR analysis, genomic DNA was amplified using the PCR machine (PE applied Biosystems) in $50 \mu$ reaction volume with the following parameters; 30 cycles of $1 \mathrm{~min}$ at $95^{\circ} \mathrm{C}, 1 \mathrm{~min}$ at $60^{\circ} \mathrm{C}$, and $1 \mathrm{~min}$ at $72^{\circ} \mathrm{C}$ and a final 8 -min extension period. PCR with the following NEO' primer and exon $93^{\prime}$ primer (CR3'); Neo-pgk primer: 5'-CGAGATCAGCAGCCTCTGTTCC-3' CR3': 5'-CCAACTCCATGCCCTGTG-3'.

Southern blot analysis was performed using $10 \mu \mathrm{g}$ of genomic DNA isolated form PCR-positive pig fetal fibroblast cells was digested with EcoRI to separate normal and targeted alleles. The DNA was subjected to $1 \%$ agarose gel electrophoresis followed by blotting onto nylon membranes. The membrane was probed with a ${ }^{32} \mathrm{P}$-labeled exon 9 fragment of 13-GT by random priming, and then exposed at $-70^{\circ} \mathrm{C}$ for $48 \mathrm{~h}$ to $\mathrm{x}$-ray film.

\section{Statistical analysis}

Data were pooled from 4 replicates that had been conducted on the same treatment. Statistically signi- ficant differences between treatment groups were analyzed using analysis of variance and LSD test (Snedecor and Cochran, 1967). Differences where the $P$ value was less than 0.05 were regarded as statistically significant.

\section{Results}

\section{3-Gal targeting strategy}

To construct targeting vector, the pig $\alpha-1,3-$ galactosyl transferase (13-GT) gene was cloned from swine genomic library and characterized. The targeting vector was designed to be able to use positive-negative selection described by Mansour et al. (1988). The vector was constructed from 8-kb 13-GT genomic DNA fragment containing part of intron 7 through part of intron 8 as a long arm and $0.75 \mathrm{~kb}$ of exon 9 as a short arm for homologous recombination events to remove part of intron 8 and exon 9 and replacing it by neomycin phosphotransferase (Neo') gene (Figure 1). In addition, the herpes simplex virus TK gene was placed at the $3^{\prime}$ end of the construct. The linearized targeting vector was introduced into pig fetal fibroblast cells by electoporation and the cells were

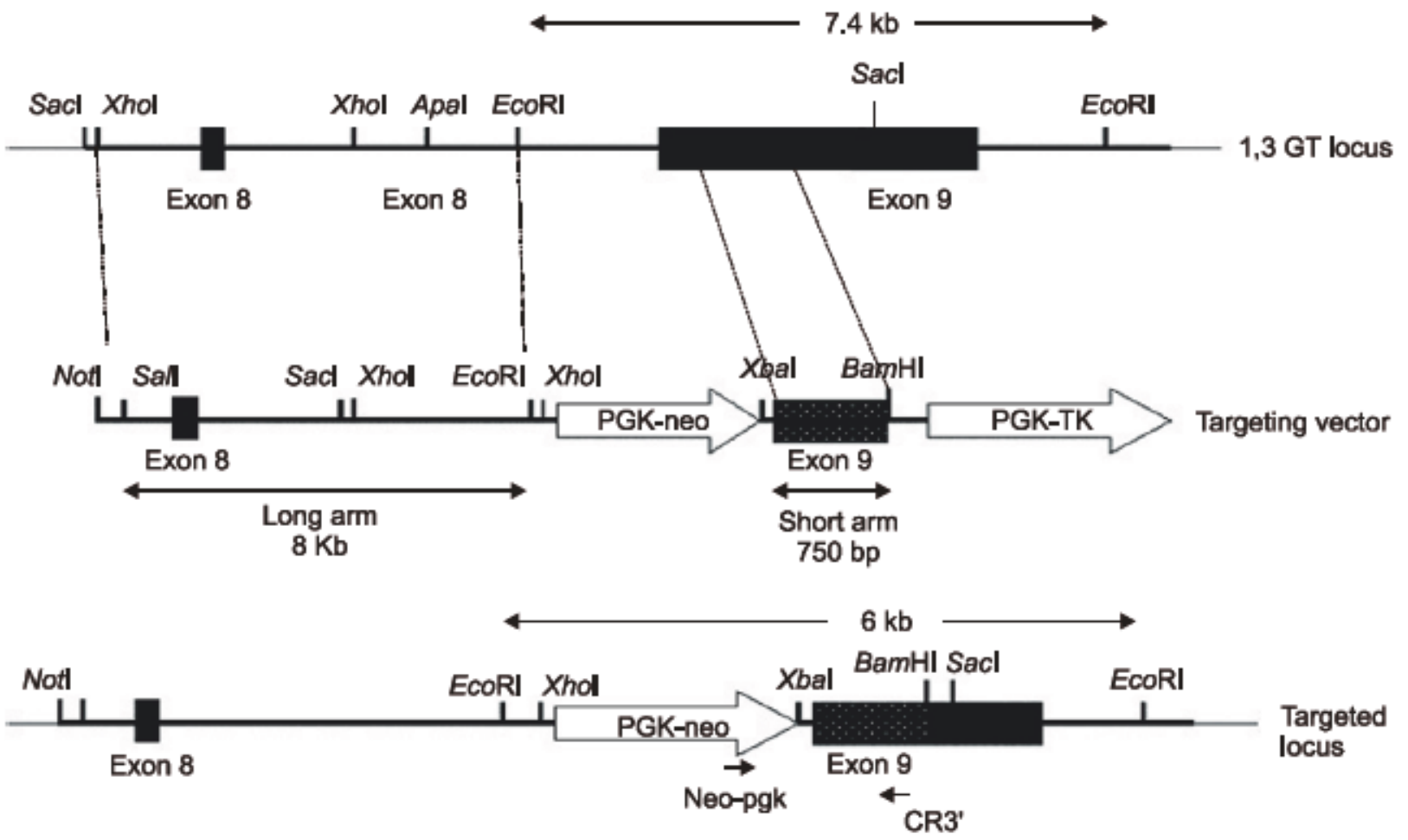

Figure 1. Targefing vector construction. Diagram of the porcine 13-GT locus, the corresponding 13-GT genomic sequences used as 5' and $3^{\prime}$ arms in the 13-GT knockout vectors, and the structure of the targeled locus after homologous recombinafon. The names and posifons of the primers used for PCR are indicated by short arrows. Neo-pgk: 5'-CGAGATCAGCAGCCTCTGTTCC-3'; CR 3': 5'-CCAACTCCATGCCCTGTG-3'. The predicled size of bands with EcoRI digesion, for both the endogenous 13-GT locus and the 13-GT targeted locus, is indicated. 
cultured in medium containing G418 plus gancyclovir to enrich for recombinants carrying the neo' gene targeted into one of the endogenous 13-GT loci.

Correctly targeted clones were primarily detected by PCR analysis using forward primer in the $\mathrm{Neo}^{r}$ gene and reverse primer in outside of short arm fragment unique to the targeted locus (Neo-pgk primer

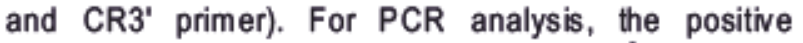
control vector was constructed using neo' gene and the whole exon 9 fragment.

\section{Targeting analysis}

Cell colonies surviving positive-negative selection with G418 and gancyclovir were assayed by PCR amplification with target locus-specific primers to amplify DNA fragment from $3^{\prime}$ end of neo gene through inside of exon 9 resulting in amplification of $1.3 \mathrm{~kb}$ DNA fragment (Figure 2A). Positive control vector and correctly targeted locus allow this fragment amplification following PCR. Pig fetal fibroblast cells (PFF) that gave positive PCR signal were potential recombinants in 13-Gal locus.

To confirm the occurrence of the targeted recombination, Southern blots of genomic DNA isolated form PCR-positive PFF clones or normal untargeted PFF, digested with EcoRI restriction enzyme were probed with exon 9 DNA fragment. Identification of PFF correctly targeted with targeting vector is illustrated in Figure 2B. The exon 9 probe hybridizes to $7.4 \mathrm{~kb}$ of the wild type allele and $6 \mathrm{~kb}$ of fragment of correctly targeted allele for EcoRI digestion. The targeted cells gave a normal wild type allele (7.4-kb band) and a disrupted allele (6-kb band), while intact cells had wild type alleles.

\section{Targeting efficiencies}

The proliferation of pig fetal fibroblast cells was sensitive to exposure of selection drugs. Following trans- fection with targeting vector DNA and drug selection, the formation of colonies was severely suppressed in the medium containing G418 or G418 plus gancyclovir. Furthermore, many colonies following drug selection could not proliferate in normal medium enough to expand cells for DNA analysis. Increase of serum

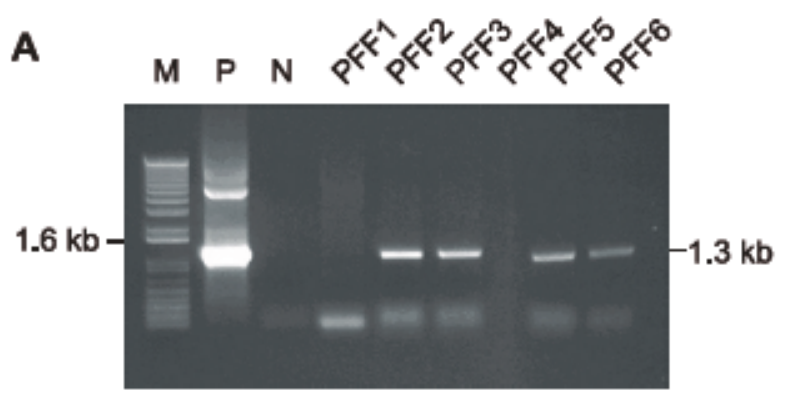

B

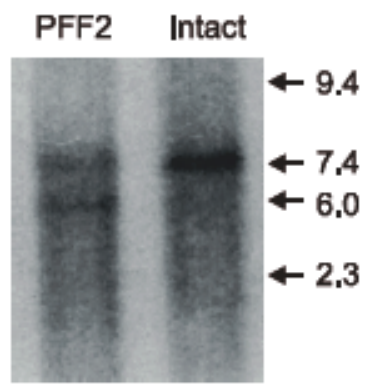

Figure 2. PCR analysis of targeled 13-GT Locus using neo-side primer and primer of $3^{\prime} 13-G T$ (A) and Southern blot analysis of 13-GT brgeted locus in pig fetal fibroblast cells (B). Approximately 1,000 cell DNA were used for PCR, with Neo-pgk as the Grward primer and CR3' as the reverse primer (A). Two negative controls, waler, and wild-type (PFF1) cells, were used to ensure that the PCR reaction was not contaminated. PFF2, PFF3, PFF5 and PFF6 were individually targeted colonies. A posifive-control vector was included, at dilutons from 100 coples. Southem blotting with PFF2 genomic DNA represented two different sizes of alleles following EcoRI digeston (B). Only one band showed up in wild-type cell lane (hract lane).

Table 1. Colony growth of pig embryonic fibroblast cells with serum concentration following transfection with targeting vectors and hen drug selection.

\begin{tabular}{cccc}
\hline \multirow{2}{*}{$\begin{array}{c}\text { Serum } \\
\text { concentrafion }\end{array}$} & $\begin{array}{c}\text { No. cells picked up } \\
\text { following selection }\end{array}$ & \multicolumn{1}{c}{ Colonies win senescence $^{*}$} \\
\cline { 3 - 4 } & 120 & $19.3 \pm 18^{t}$ & $G 418^{\mathrm{a}}+$ Ganc $^{\mathrm{a}}$ \\
\hline $5 \%$ & 120 & $20.5 \pm 4.31^{\mathrm{a}}$ & $53.5 \pm 6.08^{\mathrm{a}}$ \\
$10 \%$ & 120 & $7.3 \pm 2.72^{\mathrm{b}}$ & $45.2 \pm 9.18^{\mathrm{a}}$ \\
$20 \%$ & 120 & $10.7 \pm 3.98^{\mathrm{ab}}$ & $15.3 \pm 2.29^{\mathrm{b}}$ \\
\hline
\end{tabular}

avalues within columns with different superscripts are significantly different $(P<0.05)$.
"Colonies could not proliferate enough to screen genomic DNA bollowing drug selection. 
Table 2. Targeting efficiency in pig fbroblast cells.

\begin{tabular}{ccccc}
\hline $\begin{array}{c}\text { Selective } \\
\text { marker genes }\end{array}$ & $\begin{array}{c}\text { No. cells } \\
\text { treated }\end{array}$ & Colonies & No. colonies \\
targeted
\end{tabular}

concentration in medium could reduce the number of senescent colonies after drug selection (Table 1). Fifteen percent or higher of serum yielded significantly less senescent colonies than lower serum concentration in medium containing G418 only or G418 plus gancyclovir.

To determine the difference in targeting efficiency of single selection (G418 only) and double selection (G418 plus gancyclovir), $2 \times 10^{6}$ PFF were initially electroporated with targeting vectors that contained neo' gene only or neo' gene plus TK gene followed by drug selection for 10-14 d. Resistant colonies were counted and transferred to 24-well plate for expansion. The results of two selection experiments are summarized in Table 2. The electroporation of $2 \times 10^{6}$ PFF yielded an estimation of 300 colonies which survived the G418 selection. The $345 \mathrm{G} 418$-resistant colonies in transfectants with targeting vector containing neo' gene only were screened for targeting by PCR and one colony was identified targeted in 13-Gal locus. A total of 68 colonies originated from cells transfected with a targeting vector carrying neo' gene plus TK gene were doubly resistant to G418 and gancyclovir, and 4 of these colonies were identified to contain targeted alleles. The targeting frequency in this experiment was about $1 / 345$ of the G418-resistant colonies $(0.28 \%)$ and $4 / 68$ of G418 puls gancyclovirresistant colonies $(5.9 \%)$.

\section{Discussion}

The experiments presented here demonstrated the novel use of positive-negative selection system for gene targeting in somatic cells. Recent studies that disrupted genes in somatic cells for nuclear transfer have used positive selection only using $\mathrm{Neo}^{\prime}$ gene (McCreath et al., 2000; Denning et al., 2001; Dai et al., 2002; Lai et al., 2002; Ramsoondar et al., 2003). Large variations in the number of targeted colonies versus the number of random-integrated colonies $(1 / 20$ to $1 / 500)$ for gene targeting in somatic cells have been reported (Denning et al., 2001; Dai et al., 2002; Ramsoondar et al., 2003). In our experiments, the efficiency of single selection with $\mathrm{G} 418$ was 1 in
354 that was similar to that of reports. However, double selection in our experiments contributed to cut down number of colonies to screen and gave better efficiency for gene targeting. One of the advantages of positive-negative selection is the elimination of cells with correctly targeted alleles plus random integration of targeting vectors that have the possibility to disrupt other locus in the genome. Those cells probably cannot be effectively excluded by single selection with Neo' gene. Only Southern blotting can sort out correctly targeted cells with proper restriction enzymes among those cells. Dai et al. (2002) pointed out that the number of targeted somatic cells identified with PCR was dramatically reduced following Southern blot analysis. Double selection could probably diminish the discrepancy between results of PCR and Southern blot analysis following drug selection procedures. Promotertrap targeting vector strategy is another positivenegative selection system without using gancyclovir for the elimination of random integration events (Harrison et al., 2002).

It has been shown that many colonies were senescenced following drug selection during gene targeting procedure (Denning et al., 2001). Genetic modifications in cells in vitro require intensive drug selection and cell passages. Primary cells are very sensitive to exposure into selection drug, causing cell division crisis following selection. Increase of serum concentration in growth medium could overcome proliferation problem of fetal fibroblast cells following drug treatment during drug selection (Table 1). It could contribute to improve the overall efficiency for gene targeting in somatic cells by rescuing senescent cells with correctly targeted alleles.

The frequency of successful gene targeting in somatic cells will also depend on transfection condition of targeting vector DNA and amount of vector DNA for transfection. Proper adjustment of these conditions would be required to achieve efficient gene targeting in somatic cells. Ultimately, both allele targeting in somatic cells before nuclear transfer would accelerate the practical application of gene targeting in animals. Positive-negative selection may be especially useful in knockout procedure of both alleles at a particular locus without random integration at other 
loci for fine genetic modification in mammalian cell system.

\section{Acknowledgement}

This work was supported by the Korea Research Foundation Grant (KRF-1998-F0094).

\section{References}

Betthanser J, Forsberg $E$, Augenstein $M$, Childs L, Ellertsen K, Enos J, Forsythe T, Golueke P, Jurgella G, Koppang R, Lesmeister T, Mallon K, Mell G, Misica P, Pace M, PfisterGeneskow M, Strelchenko N, Voelker G, Watt S, Thompson $S$, Bishop $M$. Production of cloned pigs from in vitro systems. Nature Biotech 2000;18:1055-9

Capecchi MR. Altering the genome by homologous recombr nation. Science 1989;244:1288-92

Cibell JB, Stice, SL, Golueke PJ, Kane JJ, Jerry J, Blackwell C, Leon AP, Robl JM. Cloned transgenic calves produced from nonquiescent fetal fibroblasts. Science $1998 ; 280: 1256-8$

Dai YD, Vaught T, Boone J, Chen SHJ, Phelps C, Ball SA, Monahan JM, Jobst PJ, McCreath KE, Lamborn AL, CowellLucero JD, Wells K, Colman AA, Polejaeva IL, Ayares D. Targeted disruption of the $\alpha-1-, 3$ galactosyltran sferase gene in cloned pigs. Nature Biotech $2002 ; 20: 251-5$

Denning C, Burl S, Ainslie A, Bracken J, Dinnyes A, Fletcher J, King T, Ritchie M, Ritchie WA, Rollo MP, de Sousa, Travers A, Wilmut I, Clark A. Deletion of the $\alpha(1,3)$ galactosyl transferase (GGTA1) gene and the prion protein (PrP) gene in sheep. Nature Biotech 2001;19:559-62

Harrison SJ, Guidolin A, Faast R, Crocker LA, Giannakis C, D'Apice AJ, Nottle MB, Lyons I. Efficient generation of alpha $(1,3)$ galactosyltransferase knockout porcine fetal fibroblasts for nuclear transfer. Transgenic Res 2002;11:143-50

Lai L, kolber-Simonds D, Park KW, Cheong HT, L.Greenstein J, Im GS, Samuel M, Bonk A, Rieke AN, Day BN, Murphy CB, Carter DJ, Hawley RS, Prather R. Production of $\alpha-1$, 3-Galactosyltransferase Knockout Pigs by Nuclear Transfer Cloning. Science Express Report 2002;295:1089-9-92

McCreath KJ, Howcroft J, Campbell KHS, Colman A,
Schnieke AE, Kind AJ. Production of gene-targeted sheep by nuclear transfer from cultured somatic cells. Nature 2000; 405:1066-9

Mansour SL, Thomas KR, Capecchi MR. Disruption of the proto-oncogene int-2 in mouse embryo-derived stem cells: a general strategy for targeting mutations to non-selectable genes. Nature 1988;336:348-52

Onishi A, Iwamoto M, Akita T, Mikawa S, Takeda K, Awata $\mathrm{T}$, Hanada $\mathrm{H}$, Perry ACF. Pig cloning by microinjection of fetal fibroblast nuclei. Science 2000;289:1188-90

Phelps CJ, Koike C, Vaught TD, Boone J, Wells KD, Chen SH, Ball S, Specht SM, Polejaeva IA, Monahan JA, Jobst PM, Sharma SB, Lamborn AE, Garst AS, Moore M, Demetris AN, Rudert WA, Bottino R, Bertera S, Trucco M, Starzl TE, Dai Y, Ayares DL. 2003. Production of alpha 1,3-galactosyltransferase-deficient pigs. Science $2002 ; 299: 411-4$

Polejaeva IA, Chen SH, Vaught TD, Page RL, Mullins J, Ball $S$, Dai $\mathrm{Y}$, Boone J, Walker S, Ayares DL, Colman A, Campbell KHS. Cloned pigs produced by nuclear transfer from adult somatic cells. Nature 2000;407:86-90

Ramsoondar JJ, Machaty Z, Costa C, Williams BL, Fodor WL, Bondioli KR. Production of alpha 1,3-galactosyltransferase-knockout cloned pigs expressing human alpha 1,2fucosylosyltransferase. Biol Reprod 2003;69:437-45

Riele HT, Maandag ER, Berns A. Highly efficient gene targeting in embryonic stem cells through homologous recombination with isogenic DNA constructs. Proc Natl Acad Sci USA $1992 ; 89: 5128-32$

Schnieke AE, Kind AJ, Ritchie WA, Mycock K, Scott AR, Ritchie M, Wilmut I, Colman A, Campbell KHS. Human factor IX transgenic sheep produced by transfer of nuclei from transfected fetal fibroblasts. Science 1997;278:2130-3

Snedecor GW, Cochran WG. 1967. Statistical Methods, The lowa State University Press, Ames, IA, USA

Wilmut I, Schnieke AE, McWhir J, Kind AJ, Campbell KHS. Viable offspring derived from fetal and adult mammalian cells Nature $1997 ; 385: 810-3$

Zakhartchenko V, Mueller S, Alberio R, Schernthaner W, Stojkovic $M$, Wenigerkind $H$, Wanke R, Lassnig $C$, Mueller $M$, Wolf $E$, Brem G. Nuclear transfer in cattle with nontransfected and transfected fetal or cloned transgenic fetal and postnatal fibroblasts. Mol Reprod Dev 2001;60:362-9 